\title{
On becoming political: The political in subjectivity
}

\author{
Jouni Häkli* \\ Space and Political Agency Research Group \\ School of Management \\ FI 33014 University of Tampere, Finland \\ Kirsi Pauliina Kallio \\ Space and Political Agency Research Group \\ School of Management \\ FI 33014 University of Tampere, Finland
}

\section{Biographies:}

Jouni Häkli is professor of regional studies and the leader of the Space and Political Agency Research Group (SPARG) at the University of Tampere. He is also the vice director of the Academy of Finland Centre of Excellence (RELATE). His research focuses on political agency, political subjectivity, transnationalization, citizenship, and border studies.

Kirsi Pauliina Kallio is an Academy Fellow at the University of Tampere. Her research interests include political subjectivity and agency, political geographies of childhood and youth, transnational children's rights, mundane forms of citizen participation, and the everyday practice of democracy.

* Jouni Häkli is corresponding author, contact details:

Email: jouni.hakli@uta.fi

Phone: +358-40-1973664

Web: http:// www.uta.fi/jkk/ yhteystiedot/ hallintotiede/ hakli.html 


\title{
On becoming political: The political in subjectivity
}

\begin{abstract}
This article explores mundane political agency. We introduce the notion of the political ordinary as agency based on the capacity of human beings to carry out acts that are undetermined and unexpected, and thus capable of challenging, opposing, negotiating, maintaining, and readjusting prevailing conditions. We approach subjectivity from a pragmatist and phenomenological point of view and argue that it is the condition of possibility of political agency. The paper demonstrates how political subjectivity can be located in the ways in which people take up issues that stand out as important to them. To this end we look into the everyday life experiences of an eleven-year-old girl whose struggles related to proposed subject positions provide examples of mundane political agency. We conclude by arguing that political agency is the subject's action when in a state of becoming prompted by future-oriented demands and contingencies of social life.
\end{abstract}

\section{Keywords}

subjectivity; the political; agency; temporality; attentiveness; everyday life 


\section{On becoming political: The political in subjectivity}

\section{Introduction}

Political subjectivity is a notion that spans a vast conceptual space. Its perimeters range from a traditional search for the substantial subject of politics in entities such as the state, civic movements, or individuals, all the way to the total dissolution of the subject of politics in radical posthumanist philosophies. These two positions not only mark the opposite extremes in the understanding of the subject of politics, but they also represent two major impasses in attempts to theorize political subjectivity. Where the former fails to address the constitutive power that politics has on the subject, the latter runs at odds with intentionality as a practical and ethical facet of politics by expelling human subjectivity from political agency (Häkli 2017; Prozorov, 2014; Rahimi, 2016; Schmidt, 2013).

Seeking to move beyond both substantialist and anti-subjectivist ideas, a growing multidisciplinary literature has emerged to explore alternative views about the formation of political subjectivity. This work has been premised upon the idea that subjectivity should be seen "as more than a subsidiary effect, as more than the sum total of combined discursive positions", and hence what is needed is "a new order of theorization, a new conceptualization of the subject" (Blackman et al, 2008, pp. 7-8). Building on a non-dualistic understanding of the subject, this scholarship has been fueled by the need to develop a better understanding of political agency and power relations, particularly in settings that are peripheral from the point of view of mainstream political analysis (e.g. Ataç et al, 2016; Boudreau et al, 2009; Isin, 2009, 2012; Jarman et al, 2002). In consequence, also the 'what' of politics has been rethought, and the notion of the political has expanded to denote a broad spectrum of issues, events, sites and ways of acting, affecting and impacting. 
Explorations into political subjectivity have re-animated classical questions on how to conceive of the subject and how human beings can theorize about themselves as acting agents (McNay, 2010). In the process, the term has gained multiple conceptual tones ranging from human experience to psychological processes and affective states, from constructions of selfhood to the constitution of the subject in relation to power and domination (Butler, 1997; Dikeç, 2013; Glynos and Stavrakakis, 2008; Isin, 2009; Ní Mhurchú, 2016). While the question of political subjectivity is, hence, embedded in various philosophical and theoretical positions, some common ground exists, such as the understanding that the self-controlled rational subject is a defunct notion, that subjectivity is at once deeply personal and fundamentally social, and that political subjectivities emerge through relational dynamics and exceed determination by power structures (e.g. Abrams, 2015; Blackman et al, 2008; Moon, 2013; Walkerdine, 2015).

One of the greatest challenges for theorizing political subjectivity from these starting points relates to the question of how to identify politics as it happens in the world. How do we know what is political for whom in the flux of everyday life, in its multilayered spatial and temporal complexities? By introducing the idea of 'political ordinary' this paper portrays political subjectivity as a dynamism whereby the political subject arises from and is constituted by everyday political agency. To this end we present a piece of analysis from our recent study with children whose subjective lifeworlds we have explored. The analysis mainly engages with the experiences of an eleven-year-old girl, Anna Lena. On this basis we discuss how subjectivity can, and as we argue, should be seen as the condition of possibility of mundane political agency. Our main purpose is to develop a deeper understanding of political subjectivity located in everyday experiences that are related to key moments of mundane politicization. To conclude we discuss what the analytical tools we propose may have to offer 
to the contextual theorization of political subjectivity and theoretically informed empirical study of mundane political agency.

\section{Analyzing political subjectivity through children's experiences}

As understood here, political subjectivity is not an age-specific matter and thus can be traced from children's lives just as well as it can be located in the lives of adults. In fact, in our longstanding research with children and young people we have come across lives, events, situations, and narratives that are veritably filled with indications of mundane political agency (Kallio 2007; Kallio and Häkli 2011; Häkli and Kallio 2014). They reflect matters of importance, moments of interruption in life routines, attentiveness to situations characterized by the open-endedness and ambiguity over what transpires in the future, and engagement with things at stake that translate into certain acts in their everyday lives. Characteristic to these agencies is their seemingly non-political nature; in a traditional political analysis they would probably be considered rather insignificant. Yet, for our attempts to rethink the political subjectivities of everyday life, children's lived worlds are particularly opportune precisely because they fall outside what is conventionally understood as political matters (on children's politics, see Elwood and Mitchell 2012; Kallio and Häkli 2013; Marshall 2016; Skelton and Valentine 2003; Wood 2016).

While children are in many ways similar political agents to adults, it is clear that their position as minors in society conditions their agencies in various ways (Kallio and Mills 2016; Philo and Smith 2013). This needs to be kept in mind especially when discussing children's mundane politics in different kinds of societal and cultural contexts (Beazley and Miller 2016; Habashi 2017). Yet, when focusing on children's experiences and the subjectivities through which they become active agents in their everyday lives, their position as minors is but one contextual factor among others against which to negotiate their agencies. 
For this reason our analysis does not pay particular attention to children's minor position unless this comes to be reflected as part of an experience or subjective response that stands out as important to the child in question.

The analysis draws upon our recent study with eleven-to-sixteen-year-old children and young people in settings where socio-economic, ethnic, or other differences are not particularly striking. ${ }^{1}$ Rather than concentrate on the everyday politics of school life, like many school ethnographic projects, this study sought to access our participants' political agencies more broadly as experienced, developed and practiced in their lived worlds. The goal was to achieve a thick description of their experienced realities, accounts that we term dialogical place-based biographies (Kallio 2016). A major challenge in our field work, that we identified from early on, was accessing our participants' political subjectivities as this dynamism cannot be engaged with directly. Arendt (1958, p.181) describes the difficulty of grasping subjective being as follows: "The moment we want to say who somebody is, our very vocabulary leads us astray into saying what he is". Hence, mindful of this challenge, we set out to be sensitive to the modes in which our participants talked about themselves with reference to different identities, including articulated and bodily expressions as indications of their subjectivities at play in different situations (cf. Callaghan et al, 2016; Ehrkamp, 2013; Gökariksel, 2009).

The following analysis is based on the biography of Anna Lena, one of the participants who we had an intense dialogue with. ${ }^{2}$ We do not take up her experiences due to their particularity - many of our participants shared with us events and situations foregrounding the aspect of being a particular kind of social self and how this varies in different contexts. What spoke to us in Anna Lena was her ability to make explicit some moments in which her sense of self was contested, both articulately and through embodied gestures (e.g. using different tones of voice, changes in bodily appearance). As Callaghan, Alexander and Fellin (2016, p. 
411) note, "symbolically concatenated experiences [...] are not easily expressible in words", and hence attention to non-articulate forms of expression is important (see also Ivinson and Renold, 2013). In the following we let Anna Lena's experiences portray the dynamism of political subjectivity and politicization in her everyday life.

\section{You can call me "Annie": The subject's relative autonomy}

We got to know Anna Lena as an eleven-year-old girl living in a one-family house with her mother, little sister and a dog. Besides going to school and spending time with her friends, she likes to take the dog out and go to stables for horse riding. On a less cheerful note Anna Lena conveyed that her parents had recently divorced. It turned out that she and her sister visit their father and also their grandparents on a regular basis, and travel to meet up with other relatives during weekends and vacations. Anna Lena did not talk much about her performance in school but we understood that it is on good average level, and that she is more or less content with this. Hence, in most accounts we learned to know Anna Lena as an "ordinary girl" in the cultural and socio-economic contexts of her everyday life. For a conventional political analysis this might suggest that her life is securely distant from things political. Yet, as will become apparent in the next two sections, she is actually very much involved in the mundane politics of her everyday life.

In our first discussion with her, Anna Lena chose to walk us through her lived world, telling about her home, daycare, hobby, and school life. She had moved to her present neighborhood and joined her school class as a second-grader, ending up as a newcomer in a class that had all been together since kindergarten. On her first day at school her new classmates asked what to call her, and without much thinking Anna Lena had said "Annie". This was a nickname that her nanny had coined when she was about five years old and used only by her until Anna Lena took it up in the new school. She went on to note that usually she 
was called "Lena": "At home I'm always Lena, and have always been, and at school I'm Annie”. So we learned that Anna Lena uses her given name in official situations and with strangers, "Annie" at school and with new friends, and "Lena" in her family and with friends from years before the present school.

After getting to know Anna Lena better we realized that she was well versed in moving between her different social selves, and that through her nicknames she was actually articulating different identity constructions. She could reflect on their distinct character and activities, for instance by stating "Annie might go and lay down in a puddle but Lena could never do that”. We read this reflection as illuminative of Anna Lena's subjectivity involving the experience of a distinction between her sense of self and identities. We therefore took it as an entry point for exploring her capacity to problematize experience related to proposed subject positions (see also Nicolaisen, 1999; Kim and Lee, 2011).

During our discussions Anna Lena indicated various ways in which she positions herself and acts through the provided subject positions. These practices range from caring relationships to caution in risk taking to struggling with family strains to challenging adult authority, involving matters and unfolding in situations where she has things at stake. We read these as instances where Anna Lena is prompted to negotiate her identities in her everyday life. The next section presents one example of how her political subjectivity gained momentum as she challenged her familial subject positions.

\section{Subjective positioning in a familial struggle}

"Our parents usually take us [to the Granny's], me and my sister, when they need to work extra time, or we take a bus, and then we stay there for some time. [...] Granny makes good food, and she is fun and has lots of different hobby stuff, and she has this nice cat, old and chubby but anyways [...] and Grandpa is kind though he's like over seventy - he always asks what we kids would like to do, and even if we've been to the Granny's the whole day he still wants to cook us a proper meal." (Anna Lena) 
During our dialogue Anna Lena was very keen on talking about her family relationships. The above excerpt introduces two persons who have a special place in her life: the paternal grandparents who have taken care of her and her sister throughout their childhood. In addition to such happy memories and caring relations, we learned that she had encountered contradictory expectations and demands with them, particularly her Granny. Anna Lena's openness about the growing strain in these relationships suggested to us that they form an important facet of her life.

In discussing her grandparents Anna Lena was always careful to indicate that, for her, the positive experiences outweigh the negative ones. For example when talking about her relationship with "Granny", she first noted that she and "Grandpa" had divorced well before she was born but this had not prevented them from helping Anna Lena's parents with child care. In fact, the paternal grandparents live close to each other, and the sisters often stay either with Granny or Grandpa when their parents have long hours at work, coming and going between the two houses more or less as they please.

However, Anna Lena added that for a couple of years she had been experiencing uncomfortable feelings at Granny's place. We understood that these feelings were largely due to Granny's increasingly pronounced opinion that she was being neglected by Anna Lena's parents, and that they had developed a pattern of similar situations with some other close relatives. Anna Lena told us that she was sad and anxious because Granny had started to convey these familial strains openly to her, blaming her too for taking Grandpa's side in their decades-long opposition. Anna recalled vividly Granny's dissatisfaction with her parents: "[Granny] then said that 'they have estranged many important people from around you; your [maternal] Grandfather is alone dying from sorrow, and his wife is dying from sorrow, and Granny is dying from sorrow, and you too are abandoning me now' [...]" 
Adding to the complexity of the situation, Anna Lena conveyed to us that she and her sister get along very well with their Grandpa. She described at length how, when staying at his place, Grandpa takes good care of them and organizes fun activities, but also allows the girls themselves to decide what they want to do. This includes that they are always allowed to spend time also with Granny if they wish. We began to fully grasp the challenges Anna Lena was facing in her familial life when she took up her parents' position in the situation. With some frustration she declared that currently her mother and father find Granny unstable, and added that her parents and other paternal relatives are in fact no longer in contact with the embittered Granny: ”They said 'we've about had it with Granny'." Hence, it turned out that while Anna Lena enjoys a considerable flexibility in visiting her grandparents, the flipside is that she has found herself in a most awkward position as an arbitrator between her parents, Grandpa and Granny (a situation not uncommon in post-divorce families; Haugen, 2007).

When we asked Anna Lena how she feels about the situation she stated that she likes to visit the Granny but often feels guilty about not spending enough time with her. We also learned that she was rather uncomfortable with having to please both her parents and her grandparents, and that she had thought about changing the situation either by being more agreeable with Granny or visiting her less often.

Interviewer: "Who gets to decide on whether you visit her or not?"

Anna Lena: "Well, I can decide that on my own."

Interviewer: "Ok, I see."

Anna Lena: "It's too bad really, because I'd like to go there but then if

I don't visit her for a couple of days it automatically means that we've abandoned her."

Interviewer: "Right." 
Anna Lena: "So, in the end I don't want to go there. Either I should spend all my time there or not go at all - it's kinda annoying, you know."

Interviewer: "Have you ever tried to make her see things differently?" Anna Lena: "Sure, like this one time when she said that you can decide yourself whether to visit me or not, and when you don't come I know you don't want to."

Interviewer: "So, did you then say something to her?"

Anna Lena: ”Well, I said something like 'I really want to come but sometimes just can't make it', to which she said that Granny is not so stupid as to believe that."

When describing her difficult experiences with the situation, Anna Lena was tensioned and spoke breathlessly. Hence, we were struck with the change in her being when she took up her affectionate relationship with Granny: "She is like a really very pleasant person, real nice in other ways [...] she is pleasant and she has a nice garden and everything, but when she starts the blaming again then it's really drab, and there's like nothing that would make her stop." Similar bodily gestures that occurred throughout our discussions testified that to Anna Lena Granny was a very close, even if controversial, family member.

However, we also understood that to Anna Lena the strength on this relationship had developed into a double-edged sword. She told us that with her little sister she was the only remaining relative still keeping in touch with Granny. In this situation she could not help feeling that Granny had fastened onto her as a kind of a co-victim in the game ruled by the generation in between them: "[Granny] then said that 'it is so agonizing when your own children abandon you, so don't you just ever abandon your own parents'." On top of this her 
parents, for their part, blame Granny's 'condition' for the whole situation, thus deepening the cleavage between themselves, Anna Lena and Granny: "Mom said this is enough, that she is getting so crazy that soon she won't let us visit her anymore." Finally, Grandpa's care for the girls feels particularly affectionate to Anna Lena, as he has not put pressure on her but instead allows her to choose for herself how to keep up the intergenerational relations in the difficult situation: "Grandpa is so lovely, he's turning seventy one this year, and he's just so nice and fair."

We learned that in the midst of this discord, Anna Lena's experience of her familial relationships had problematized to the point where she had become attentive to several aspects of the crisis. In upholding the contested family relationships, Anna Lena found herself as an arbitrator between Granny and Grandpa: "We'd been at Granny's for three days, and then with Grandpa for two days, and when we then went to see Granny again she said that Grandpa just tries to keep you busy so that you couldn't get here [...]” Moreover, Anna Lena has a major role in either continuing or reversing the intergenerational fragmentation of her family because she and her little sister are the only persons who are in communicative relationships with all parties of the family situation, including her parents, herself and her sister, her paternal and maternal grandparents, and indirectly also some other close relatives. Above we have examined these familial relations as they are reflected in Anna Lena's dialogical biography. We now move into discussing her experiences and actions in terms of what we call the political ordinary. ${ }^{3}$

\section{The idea of 'political ordinary'}

As the above discussion shows, the question of Anna Lena's subjectivity is closely related with the phenomenologies of her agency (see also Abrams 2015; Barnett, 2012). To focus on the phenomenology $\mathrm{y}^{4}$ of human agency has particular appeal when it comes to making sense of 
the politics of everyday life (Knies, 2001; Melançon, 2010). It conveys the idea that we should not preclude seemingly commonplace, uninteresting or unremarkable events from the analysis of political agency, as these too may be significant for the ones involved. The phenomenological apprehension of mundane agency thus opens up for the possibility of studying the politics of "living together" as it unfolds in the world (Arendt 2005, p. 21).

The idea of 'political ordinary' may at first glance seem antithetical to the conventional understanding of politics as matters of particular import. However, at stake with the notion of ordinary is not importance per se, but rather the way in which, and by whom, this importance is recognized. This is precisely where the phenomenology of everyday life comes into play; it allows for an understanding of politics where the significance and importance of issues is an emergent part of everyday experience, not a pre-given fact. This is not to say that the experiencing subject is a static substance in itself, or that the political ordinary only occurs through people's immediate encounters (see also Bleiker, 2003; Callaghan et al, 2016; Ivinson and Renold, 2013). On the contrary, present social existence is always intersubjective and as contextually embedded it has a history and a future (Emirbayer and Mische, 1998; Rahimi 2016). These socio-spatial and temporal conditions of subjective experience effectively enmesh the emergent political ordinary with collective and institutional politics to the point where the distinction may become meaningless (e.g. Bayat, 2010; Thomas, 2011). Politics, thus understood, is a manifestly human condition, a ceaseless negotiation of the ways of living together that employs the capacities for human agency, such as attentiveness, reflexivity, affectivity, improvisation, interrogation, and the production of change (cf. Isin, 2009; McNay, 2008; Simonsen, 2013).

Viewing people's mundane life as potentially political requires some qualifications to justify the use of the term political instead of, say, social co-existence. When discussing Anna Lena's biography, we have already pointed at matters of importance as key in recognizing the 
political moment in everyday life. In a phenomenological perspective, the importance of issues can only be judged by the subjects involved. Moreover, importance is not an inherent aspect of issues but is constituted contextually, which means that the political always needs a setting where those involved have things at stake (Kallio and Häkli 2017). Recognizing the constitutive role of contextuality in mundane politics means that it cannot be understood in individualistic terms. As political agents we exist intersubjectively, share our experiences intuitively or deliberately, enact and debate norms and moralities collectively, and articulate our concerns in socially meaningful ways.

What follows is that to grasp how political agency is constituted, it is necessary to turn to people's experiences of events and situations they encounter, and focus on issues that stand out as important to them. To this end we must account for a key capacity of human subjects, which is to experience a distance between their intersubjectively negotiated social identities and their own sense of self, that is, a relative autonomy from the subject positions offered in the flux of everyday life (e.g. raced, classed, gendered, aged, familial identities) (Häkli \& Kallio 2014, see also Walkerdine, 2000). The political ordinary, thus, is "exerted through moves that are imbricated with discourses of power but also recognize and question them“ (Zanotti, 2013, p. 298). It is animated when people become attentive to social power relations embedded in particular subject positions that they end up accepting, averting or transforming. The baseline that follows is that subjectivity is both the premise of and constraint to human political agency, thus forming its critical condition of possibility.

This subjective dynamism was clearly present also in Anna Lena's life. Her longstanding attempts to maintain good relationships with both her parents and her grandparents have required constant balancing between their and her own aspirations. While she has grown somewhat tired of the strained situation, she has chosen to diverge from her parents and the broader family who have let their relationship with Granny to thin out. By continuing to visit 
her Granny, she has effectively maintained the intergenerational problematic on the family agenda. However, at the same time she has refused the subject position of 'Granny's girl', a familial role whereby she would end up taking sides with her (and other 'abandoned' grandparents from the mother's side), in opposition to her parents, her Grandpa, and the rest of the father's family. Hence, her agency is not that of an individual subject, but builds on her political subjectivity and personal experiences that are heavily conditioned by the social settings and contexts of her everyday life.

Yet, importantly, Anna Lena's political subjectivity is not reducible to these formative conditions and contexts. To make sense of the subject's relative autonomy from its social constitution, we have followed ideas developed in classical pragmatist thought (most importantly G.H. Mead's work) and the subsequent scholarship it has inspired (e.g. Colapietro, 2006; Honneth, 1995). We have found useful a Meadian understanding of subjectivity as a dialogue between the subject's "me" and "I"; two aspects of subjective existence that can only be distinguished analytically (Mead, 1934). Here "me" refers to the subject's intersubjectively constituted social self that acts as a kind of an "interface" in our encounters with others. "I", instead, refers to the embodied subject's presently ongoing agency that is always facing situations that are novel (in the sense of not being predetermined) (Markell 2007). Subjectivity, then, dwells in the irreducibility of our sense of self to our social constitution - a distance that provides us with the capacity to experience subject positions proposed to us as more or less agreeable (cf. "construction of a sense of self-as-subject", Callaghan et al, 2016, p. 415).

We argue that this experiential capacity, enabled by subjectivity, is what fundamentally animates the political ordinary. In Anna Lena's case, to avert an uncomfortable subject position, she obtained degrees of freedom in her relationship with Granny by refusing to become a 'Granny's girl'. In practical terms, she does not visit her every time she has the 
chance, and simply leaves from her place when the conditions there turn agonizing: "I still like to visit Granny but sometimes I leave for the Grandpa's instead [...] and when Granny wants me to spend all my time there, then I just don't go [...]" In so doing, she is having her way without having to choose sides. These subtle deeds, at once purposive and disruptive of the prevailing routines, are precisely what Isin (2012, p. 123) calls an act, a mark of "political subjectivity" at play (emphasis in original). They are, however, not proposing a rupture, a transgressive move that would lead to radical change, but rather are oriented toward maintaining the status quo that Anna Lena finds worth protecting.

We posit that paying attention to experiences of subject positions people encounter in their lives is key to recognizing and studying the moments that give rise to the political in everyday life (cf. Barnett, 2012; Isin, 2012; Dawney, 2013). As Anna Lena’s biography shows, in empirical terms it is feasible to focus on people's experiences of being particular kinds of social selves, as these vary between contexts (e.g. "me" in the family setting, at work, in public, in nursing and health care institutions, etc.). While people do not continuously reflect upon their sense of self, experiences of unease or gratification may increase such attentiveness to the point where it becomes the object of explicit reflection. In such instances the different facets of "me" - the identities through which we relate with our worlds - can be assessed, discussed and affected by ourselves and others.

\section{Becoming/political: temporality, attentiveness, agency}

We are yet to arrive at a more focused understanding of what constitutes the political in the flux of everyday life, distinguishing it from other facets of socio-spatially conditioned human agency. In this regard we have found helpful Sadeq Rahimi's (2016) recent discussion on the coming together of different temporal dimensions of subjective experience (see also Walkerdine, 2015). Here we elaborate Rahimi's idea of pantemporality further with the help 
of Mustafa Emirbayer and Ann Mische's (1998) thorough assessment of the relationship between temporality, the subject's experience and some key dimensions of human agency. Leaning on Mead's (1932) thought on the temporal conditions of human agency, they distinguish between the past, the present and the future as the three major orientations that shape agency. Mindful of the risks of categorical thinking, they are careful to stress that the distinction is analytical and that in any empirical agency usually all three are present to some extent. They still point out that one of the temporalities often predominates, thus giving rise to qualitative differences in the nature of human agency depending on whether it is enacting the past or rather orientated to the future as it seeks to respond to emergent events (Emirbayer and Mische, 1998).

Emirbayer and Mische (1998) characterize the three constitutive temporalities in terms of iterational (the past), projective (the future) and practical-evaluative (the present) agency. Here the iterational element refers to the ways in which the past conditions human agency through the "interpenetration of mental categories, embodied practices and social organization" that make it possible for humans to "sustain identities, meanings and interactions [...] recursively implemented in social life". Hence, iterational agency involves largely "habitual, unreflected, and mostly unproblematic patterns of action by means of which we orient our efforts in the greater part of our daily lives" (1998, p. 975). In agreement with this characterization we see iterational agency, conditioned by past socio-spatial contexts, as the 'non-political' major part of the flux of our everyday lives.

The idea of past as iterational routine differs crucially from the more conventional understanding of past as history. History as transmitted memories and past experiences carries a strong political potential when enlivened and mobilized in the context of present actions (Mitchell and Elwood, 2013). It is therefore important to remember that the past, in the sense that Emirbayer and Mische (1998) talk about it, refers simply to the fact that we are not 
constantly alerted to reflection or attentiveness to our situations, but instead carry with us habitual ways of being and relating with others. In contrast to this, when articulated in some form that people can become aware of and affected by, the past as history may gain political momentum. To use a Hegelian example, it is possible to lead a 'non-political' life as a slave if this is a routinely enacted position and identity to the person involved, but politics may begin when the person becomes aware of the ancestry of slavery. In our broader study, examples of such transitions included awakening to racist undertones of bullying in school, and the realization that difficulties to progress in education are related to socio-economic inequalities embedded in the UK school system (Kallio 2017).

In stark contrast to the stable and routine-like iteration, projectivity encompasses the ways in which humans creatively reconfigure "received structures of thought and action [... in relation to their] hopes, fears, and desires for the future" (1998, p. 971). Projective agency is shaped in response to the challenges of social life caused by uncertainty regarding some aspects of the future. Emirbayer and Mische (1998) posit that by generating alternative possible responses to the problematic situations they confront in their lives, humans "construct changing images of where they think they are going, where they want to go, and how they can get there from where they are at present" (1998, p. 971). Far from a voluntarist conception of fully informed individual strategic action, projective agency "is always an interactive, culturally embedded process by which social actors negotiate their paths toward the future, receiving their driving impetus from the conflicts and challenges of social life." (1998, p. 971).

Hence, awareness of history and the long-term formation of constraints may well be part of projectivity as long as these are problematized in the context of future-oriented agency (see also Kojéve, 1969; Rahimi, 2016). Moreover, such agency is informed by "varying degrees of clarity and detail and extend with greater or lesser reach into the future; they entail proposed 
interventions at diverse and intersecting levels of social life" (1998, p. 971). Projectivity thus involves a form of reflexivity and aspiring imagination to the extent that it is prompted by "problems that cannot satisfactorily be resolved by the taken-for-granted habits of thought and action that characterize the background structure of the social world" (1998, p. 984).

It is the future-oriented projectivity that for us sets political agency apart from other forms of social co-existence and interaction. Its condition of possibility lies in the human capacity to political subjectivity and experiential distanciation from proposed subject positions. In Mead's (1934) terms projectivity is based on subjective freedom and maneuverability in relation to established roles, that is, the imaginative capacity of the situational "I" to exist in relation to a contextually variable "me". This maneuverability enables the subject to act in unexpected ways and initiate things new in response to challenges set by one or another aspect of the uncertain future.

But what is it that prompts political agency? To account for this question we must turn to the third temporal orientation shaping human agency. The practical-evaluative aspect of agency entails responsiveness to "the emerging demands, dilemmas, and ambiguities of presently evolving situations" (Emirbayer and Mische, 1998, p. 971). Key here is the problematization of experience that brings about a moment of attentiveness toward an emergent situation, or "interruption" in the flux of mundane routines (Dawney, 2013). Attentiveness calls forth a deliberation that can be either situationally based or embedded in a broader spatio-temporal context, and conducive to either reproductive or transformative action. Hence, attentiveness may range from a clear-cut disruptive experience to an extended feeling of unease with some aspects of one's life. Importantly, when an emergent situation prompts attentiveness, humans are pushed away from their iterative forms of agency, into a state of becoming where the past and the future intersect in the form of a challenge, 
uncertainty, or conflict that demands their attention. By definition, such attentiveness is prompted by matters of importance, a challenge in which the subject has something at stake.

In terms of our conceptual approach, we found Anna Lena's positioning in her tensioned family relations an apt example of how the past and the future entwine in the political ordinary. Anna Lena is engaged in the situation as a subject whose life routines with the grandparents have been problematized. Her agency is prompted by the demands and contingencies of her familial life, weaving together her parents' and grandparents' homes as its key sites, and past rifts and omissions as its focal events. It is also characterized by considerable uncertainty and ambiguity in regard how these relationships will evolve in the future and who Anna Lena can be in her family. A degree of autonomy from roles and expectations spring from Anna Lena's subjectivity, allowing her to break away from routines, and thereby take action not determined by past events. Yet, they continue to condition her political agency as she needs to position herself in relation to what has transpired in her extended familial relations over the past years.

\section{State of becoming as the political moment}

The multiple spatial and temporal dimensions, along which the subject's attentiveness may be prompted, point at a complex and multifaceted contextuality of the political ordinary. Immediate situations may be powerfully affective, bringing about a bodily felt disruption in the flux of personal routines (Koefoed and Simonsen, 2012). For example, several participants in our broader study recalled strong emotions and anxiety from encountering poor and vulnerable people living on the street in countries like Egypt, South Africa and India. While exposed to poverty and inequality through education and the news and popular media, facing these people had struck them in ways that go beyond such cognitive processing. 
Yet, often the present situation is more broadly constituted and thus reflects a bundle of spatio-temporal relations that bring together various events, actors, sites and places. In such a case the problematization of experience may extend well beyond a momentarily interruption, coming closer to the idea of a problem or crisis in everyday life that demands more sustained attention and involves sharing with other people (e.g. Secor, 2002; Thomas, 2011). In our reading, this is precisely how Anna Lena's political agency is constituted in the context of her familial relations. Her acts, animated by subjectivity and raised by attentiveness toward problematized experiences, are prompted by the contingencies of the present as she is drawing from the past and orienting toward an unknown future. In other words, this is how Anna Lena's pantemporal political ordinary is shaping both herself and the situations where she has things at stake.

It is the responses to these kinds of challenges that we wish to term mundane political agency because they entail a purposive action to either restore the possibility to reproductive agency, or to invent transformative forms of action. Political agency, thus understood, is the subject's action when in a 'state of becoming' prompted by the future-oriented demands and contingencies of social life, and characterized by the exigencies of changing situations with considerable uncertainty and ambiguity. This agency may take different forms because activity and passivity are equally possible responses - not taking progressive action may also be an act - and humans may seek to either restore the status quo or produce change in those aspects of their lives that have become problematized.

In sum, for agency to be political it has to be distinguishable from action performed in accordance with a social order understood as conduct, discipline, practice or routine. Moreover, political agency is always purposive (albeit not necessarily intentional) and thus involves an accomplishment in the sense of having completion. Hence, "to make a difference is to act; to act is to make a difference" (Isin, 2009, p. 380). However, we insist that politics 
must not always be seen as a rupture or a turn towards change. It seems clear to us that to purposively maintain a status quo by sustaining a prevalent order or halting change can be just as significant a way of being political as is to act subversively. Instead of disruption the key to the political ordinary is in the future-oriented responsiveness to a situation based on attentiveness to power relations vested in subject positions encountered in everyday life. Based on the subject's relative autonomy, we argue, this capacity is at the root of becoming/political.

\section{Conclusion}

In this article we argue for the inclusion of ordinary acts within what is conceived of as the political. We do this to decenter the idea that political subjectivities mainly dwell in the realm where matters of public import are dealt with. We consider that it is useful to become more attuned to the plurality of political acts by recognizing that the political exists in the capacities that all human beings have, and by accepting that struggles identifiable as political deeply intertwine with the seemingly non-political ordinary aspects of life.

It is this plurality of political acts that we seek to capture with the concept of the political ordinary. The political aspects of everyday life, such as being socially related through our raced, gendered, sexed, classed, aged, and placed identities, are never purely about social power structures operating over and above our heads, but rather they are shaped through negotiations and struggles that constitute human existence at its most persistent and common levels. We share Thomas Dumm's $(1999$, p. 5) conviction that "a better understanding of the ordinary may lead to a better apprehension of some of the most important political struggles of this era". We only need to think of modern gay and lesbian movements to realize that most intimately experienced matters of importance may translate into acts that accumulate and explode into politics that nearly everyone has to relate to (Blackman et al, 2008; Ruez, 2016; 
Seidman and Meeks, 2011). Or we can point at intergenerational caring relations that currently are strained by the fragmentation of families, individuated lifestyles and transnational mobility, yet keep animating the ordinary politics of care, as was the case in Anna Lena's life (Blome et al, 2009; Kallio 2016). Acknowledging the agencies of children and young people, and others typically excluded from the realm of politics, is an important aspect in this reading of the political (cf. Callaghan et al, 2016; Ivinson and Renold, 2013).

Drawing from our empirical study with children, we have sought to demonstrate how human subjects relate with their worlds through social identities from which they have a relative autonomy. The irreducibility of the subject to its intersubjective constitution is the basis of subjectivity that we approach as the sine qua non of becoming political. Leaning on Georg Herbert Mead's and Hannah Arendt's thought, we suggest that, while we can understand our different identities as the general attributes that delineate what we are, the human ability to experience a relation to these subject positions - either accepting, averting or renegotiating them - animates our political subjectivities and gives rise to what we refer to as the political ordinary. Our analysis shows how this subjectivity can be studied by assessing experiences of situations and events that make the subjects attentive to power relations vested in the subject positions that are offered to them in their everyday life. In the presented case, acting as differently named social selves provides an entry point to grasping this dynamic. In discussions with Anna Lena we were able to enter some lived moments and situations where she employed capacities animated by her subjectivity. Her attentiveness was prompted by aspects of close relationships in which she had things at stake, and she acted politically in response to these challenges together with her significant others. These aspects of Anna Lena's life we read as evidence of her subjectivity and agency unfolding in the political ordinary. 
We consider political agency as the subject's action when in a state of becoming prompted by future-oriented demands and contingencies of social life. In the political moment people therefore appear simultaneously as acting and developing subjects. As experientially grounded in the flux of everyday life, political acts can concern anything that human subjects become attentive to, with the potential of maintaining, challenging, and transforming the conditions from which they spring. When analyzed in situations where people have things at stake, the different spatio-temporal modalities of the political intersect and enmesh, dissolving categorical distinctions between the past, present and future, as well as private and public, or personal and institutional contexts of politicization. The challenges that this line of inquiry presents, we trust, will intrigue scholars interested in deepening our understanding of political subjectivity as a mundane human condition.

\section{Acknowledgements}

We wish to thank the Academy of Finland (grant SA258341) and the RELATE Centre of Excellence (grant SA307348) for financially supporting this work, and the Space and Political Agency Research Group (SPARG) at the University of Tampere for an inspiring research environment. We are also grateful to the editors of Subjectivity and the two anonymous reviewers for their engaged and helpful comments and suggestions.

\section{References}

Abrams, T. (2015) Heidegger, subjectivity, disability. Subjectivity 8(3): 224-242.

Arendt, H. (1958) The human condition. Chicago: University of Chicago Press.

Arendt, H. (2005) The Promise of politics. (Ed. By Jerome Kohn) New York, NY: Schocken Books.

Barnett, C. (2012) Situating the geographies of injustice in democratic theory. Geoforum 43(4): 677-686.

Bayat, A. (2010) Life as politics: How ordinary people change the Middle East. Stanford: Stanford University Press. 
Beazley, H. and Miller, M. (2016) The art of not been governed: street children and youth in Siem Reap, Cambodia In: K.P. Kallio and S. Mills (eds.) Politics, Citizenship and Rights. Vol. 7 of Springer Major Reference Work on Geographies of Children and Young People (ed. T. Skelton). Singapore: Springer, pp. 263-289.

Blackman, L., Cromby, J., Hook, D., Papadopoulos, D., and Walkerdine, V. (2008) Creating subjectivities. Subjectivity 22(1): 1-27.

Bleiker, R. (2003) Discourse and human agency. Contemporary Political Theory 2(1): 25-47.

Blome, A., Keck, W. and Alber, J. (2009) Family and the welfare state in Europe:

Intergenerational relations in ageing societies. Cheltenham, UK: Edward Elgar Publishing.

Boudreau, J., Boucher, N. and Liguori, M. (2009) Taking the bus daily and demonstrating on sunday: Reflections on the formation of political subjectivity in an urban world. City 13(2-3): 336-346.

Butler, J. (1997) The Psychic Life of Power. Stanford: Stanford University Press.

Callaghan, J. E., Alexander, J. H. and Fellin, L. C. (2016) Children's embodied experience of living with domestic violence: "I'd go into my panic, and shake, really bad". Subjectivity 9(4): 399-419.

Colapietro, V. (2006) Practice, agency, and sociality: an orthogonal reading of classical pragmatism. International Journal for Dialogical Science 1(1): 23-31.

Dawney, L. (2013) The Interruption: investigating Subjectivation and Affect. Environment and Planning D: Society and Space 31(4): 628-644.

Dikeç, M. (2013) Beginners and equals: political subjectivity in Arendt and Rancière. Transactions of the Institute of British Geographers 38(1): 78-90.

Dumm, T. (1999) A Politics of the Ordinary. New York, NY: New York University Press.

Ehrkamp, P. (2013) I've had it with them! Younger migrant women s spatial practices of conformity and resistance. Gender, Place and Culture 20(1): 19-36.

Elwood, S. and Mitchell, K. (2012) Mapping children's politics: spatial stories, dialogic relations and political formation. Geografiska Annaler: Series B, Human Geography 94(1): $1-15$.

Emirbayer, M. and Mische, A. (1998) What is agency? American Journal of Sociology 103(4): 962-1023.

Glynos, J. and Stavrakakis, Y. (2008) Lacan and political subjectivity: Fantasy and enjoyment in psychoanalysis and political theory. Subjectivity 24(1): 256-274.

Gökariksel, B. (2009) Beyond the officially sacred: Religion, secularism, and the body in the production of subjectivity. Social \& Cultural Geography 10(6): 657-674.

Habashi, J. (2017) Political Socialization of Youth: A Palestinian Case Study. New York: Palgrave Macmillan.

Häkli, J. 2017. The subject of citizenship: Can there be a posthuman civil society? Political Geography (online 31 Aug 2017). doi: 10.1016/j.polgeo.2017.08.006

Häkli, J. and K.P. Kallio. 2013. Subject, action and polis: Theorizing political agency. Progress in Human Geography 38 (2): 181-200.

Haugen, G.M. (2007) Caring children: exploring care in post-divorce families. The Sociological Review 55(4): 653-670. 
Honneth, A. (1995) The Struggle for Recognition: The Moral Grammar of Social Conflicts. Cambridge: Polity Press.

Isin, E. (2009) Citizenship in flux: the figure of the activist citizen. Subjectivity 29(1): 367388.

Isin, E. (2012) Citizens without Frontiers. London: Continuum.

Ivinson, G., and Renold, E. (2013) Subjectivity, affect and place: thinking with Deleuze and Guattari's Body without Organs to explore a young girl's becomings in a post-industrial locale. Subjectivity 6(4): 369-390.

Jarman, M., S. Lamp, D. Mitchell, D. Nepveux, N. Nowell, and S. Snyder, 2002. Theorising disability as political subjectivity: Work by the UIC disability collective on political subjectivities. Disability \& Society 17 (5): 555-569.

Kallio K.P. and Häkli, J. (2013) Editorial: Children and young people's politics in everyday life. Space and Polity 17(1): 1-16.

Kallio, K.P. 2007. Performative bodies, tactical agents and political selves: Rethinking the political geographies of childhood. Space and Polity 11 (2): 121-136.

Kallio, K.P. 2016. Shaping subjects in everyday encounters: Intergenerational recognition in intersubjective socialisation. Environment and Planning D: Society and Space 35 (1): 88-106.

Kallio, K.P. 2017. Citizen-subject formation as geo-socialisation: A methodological approach on 'learning to be citizens'. Geografiska Annaler B: Human Geography 99 (4) (in press).

Kallio, K.P. and Mills, S. (2016) Editorial: Geographies of children and young people's politics, citizenship, and rights. In: K.P. Kallio and S. Mills (eds.) Politics, Citizenship and Rights. Vol. 7 of Springer Major Reference Work on Geographies of Children and Young People (ed. T. Skelton). Singapore: Springer, pp. ix-xviii.

Kallio, K.P., and J. Häkli. 2011. Tracing children's politics. Political Geography 30 (2): 99109.

Kallio, K.P., and J. Häkli. 2016. Geosocial lives in topological polis: Mohamed Bouazizi as a political agent. Geopolitics 22 (1): 91-109.

Kim, J., and K. Lee. 2011. "What's your name?": Names, naming practices, and contextualized selves of young Korean American children. Journal of Research in Childhood Education 25 (3): 211-227.

Knies, K. (2001) The politics that no one practices. Radical Philosophy Review 4(1-2): 135172.

Koefoed, L. and Simonsen, K. (2012) (Re) scaling identities: embodied others and alternative spaces of identification. Ethnicities 12(5): 623-642.

Markell, P. (2007) The potential and the actual: Mead, Honneth, and the I. In: B. Van Den Brink and D. Owen (eds.) Recognition and Power: Axel Honneth and the Tradition of Critical Social Theory. New York, NY: Cambridge University Press, pp. 100-132.

Marshall, D. (2016) Existence as resistance: children and the politics of everyday practice in Palestine. In: K.P. Kallio and S. Mills (eds.) Politics, Citizenship and Rights. Vol. 7 of Springer Major Reference Work on Geographies of Children and Young People (ed. T. Skelton). Singapore: Springer, pp. 245-262.

McNay, L. (2008) Against Recognition. Cambridge: Polity Press. 
McNay, L. 2010. Feminism and post-identity politics: The problem of agency. Constellations 17 (4): 512-525.

Mead, G.H. (1932) The Philosophy of the Present. Chicago: University of Chicago Press. Mead, G.H. (1934) Mind, Self, and Society. (Ed. By C.W. Morris) Chicago: University of Chicago Press.

Melançon, J. (2010) Merleau-Ponty's phenomenology of politics: a humanism in extension. Philosophy and Social Criticism 36(5): 623-634.

Mitchell, K. and Elwood, S. (2013) Intergenerational mapping and the cultural politics of memory. Space and Polity 17(1): 33-52.

Moon, D. S. (2013) Autonomy and alienated subjectivity: A re-reading of Castoriadis, through Žižek. Subjectivity 6(4): 424-444.

Ní Mhurchú, A. (2016) Thinking with reproduction: maternal time, citizenship, migration and political subjectivity. Subjectivity 9(1): 17-37.

Nicolaisen, W. (1999) An onomastic autobiography, or, in the beginning was the name. Names: A Journal of Onomastics 47(3): 179-190.

Philo, C. and Smith, F. (2013) The child-body-politic: afterword on 'children and young people's politics in everyday life'. Space and Polity 17(1): 137-144.

Prozorov, S. (2014) The artist of not being governed. In: Hansson, S., Hellberg, S., and Stern, M. (eds.) Studying the agency of being governed. London: Routledge, pp. 34-52.

Rahimi, S. (2016) Haunted metaphor, transmitted affect: The pantemporality of subjective experience. Subjectivity 9(1): 83-105.

Ruez, D. 2015. Working to appear: The plural and uneven geographies of race, sexuality, and the local state in Sydney, Australia. Environment and Planning D: Society and Space 34 (2): 282-300.

Schmidt, J. (2013) The empirical falsity of the human subject: New materialism, climate change and the shared critique of artifice. Resilience 1(3): 174-192.

Secor, A. (2002) The veil and urban space in Istanbul: women's dress, mobility and Islamic knowledge. Gender, Place and Culture 9(1): 5-22.

Seidman, S. and Meeks, C. (2011) The politics of authenticity: civic individualism and the cultural roots of gay normalization. Cultural Sociology 5(4): 519-536.

Simonsen, K. (2013) In quest of a new humanism: embodiment, experience and phenomenology as critical geography. Progress in Human Geography 37(1): 10-26.

Skelton, T. and Valentine, G. (2003) Political participation, political action and political identities: young d/deaf people's perspectives. Space and Polity 7(2): 117-134.

Thomas, M. (2011) Multicultural Girlhood: Racism, Sexuality and the Conflicted Spaces of Urban Education. Philadelphia: Temple University Press.

Walkerdine, V. (2000) Violent boys and precocious girls: Regulating childhood at the end of the millennium. Contemporary Issues in Early Childhood 1(1): 3-23.

Walkerdine, V. (2015) Transmitting class across generations. Theory \& Psychology 25(2): 167-183.

Wood, B.E. (2016) A genealogy of the "everyday" within young people's citizenship studies. In: K.P. Kallio and S. Mills (eds.) Politics, Citizenship and Rights. Vol. 7 of Springer Major 
Reference Work on Geographies of Children and Young People (ed. T. Skelton). Singapore: Springer, pp. 383-399.

Zanotti, L. 2013. Governmentality, ontology, methodology. Alternatives: Global, Local, Political 38 (4): 288-304.

\footnotetext{
${ }^{1}$ The field work involved 162 participants from Southern Finland and Northern England and was carried out with anthropologically oriented child-centered methods, respecting children and young people's right to decide the extent to which they wished to participate in our research, if at all.

${ }^{2}$ All names we refer to are pseudonyms and the specifics concerning the field work setting have been removed. We use throughout the name Anna Lena to refer to our participant's given name, and Annie and Lena to refer to her nicknames.

${ }^{3}$ The following analysis has close parallels with the analyses by Callaghan et al (2016), and Ivinson and Renold (2013). While not discussing political subjectivities or agency per se, we see the situations and activities they describe as apt examples of political ordinary unfolding in children's and young people's distinct mundane contexts.

${ }^{4}$ We refer to phenomenology not as a school of thought but as a particular perspective that highlights human experience at the root of political agency.
} 